\title{
ABOUT THE PROFESSIONAL REACH OF GARDEN CULTURE AND OPEN SPACE DEVELOPMENT IN GERMANY
}

\author{
Gert Groening
}

\section{On the notion of ecology}

In late twentieth century the notion of ecology is used in almost any combination, especially since the 1980s. The notion has become inflated and is applied ubiquitously, also in landscape architecture, and especially in the notion of landscape ecology. Hence it seems appropriate to briefly recall the origin of the notion of ecology.

In 1866 the German scientist Ernst Heinrich HAECKEL ( 1834-1919) published his book 'General Morphology of Organisms'. ${ }^{1}$ In it he suggested the notion of ecology in order to establish a new field of research. HAECKEL was a nineteenth century scientist whose special field were low ranking organisms of the oceans' (niedere Meerestiere). He used the results of his scientific research in order to develop what he called a theory of recapitulation". which he also named the "biogenetic law" The theory of recapitulation stated that the embryonic development (ontogeny) of an animal recapitulates the evolutionary development of the animal's ancestors (phylogeny). ${ }^{3}$

With his theory of recapitulation HAECKEL wanted to support the more general theory of evolution and there is nothing wrong with that. However, the problem with the biogenetic law is that it only applies to embryonic development and not to adult stages. As development proceeds the embryos of different species become more and more dissimilar. More than that in later stages of development the species vary according to location. HAECKEL had realized the location-specific variation of the same species. Here the biogenetic law was no longer applicable. For further study HAECKEL then suggested to go beyond comparative anatomy which had allowed to detect the biogenetic law. HAECKEL suggested to look into how animals, plants, and humans were dependent upon their specific environments. This would be a new scientific discipline for which he proposed the name of ecology. ${ }^{4}$

However, the relatively narrow terms of the biogenetic law did not keep HAECKEL from developing a mechanistic monism ${ }^{5}$ in a number of fairly speculative publications. By this monism HAECKEL wanted to explain all phenomenona on earth by one unifying principle and declare them manifestations of one single substance which would have supported his theory of recapitulation. Such theorizing was not uncommon for nineteenth century scientists. HAECKEL's version of monism was mechanistic because he only accepted the material substance as reality, not however the spiritual substance. But why bother with such a deficient nineteenth century theory?

The point is that HAECKEL claimed that what he assumed was true for plants and animals held true for humans also. Out of this attitude developed what is known as "Social Darwinism"

Garden Culture and Open Space Development, Institute for History and Theory of Design, 
According to Social Darwinism human societies should only become governed by the "best", i.e. by those who survived in the hard struggle of existence. This idea tried to impose upon humans what Charles Robert DARWIN (1809-1892), the English naturalist, had distilled from his meticulous research on plants and animals, and published in 1859 in his book "Origin of Species". ${ }^{6}$ DARWIN called what he had found from his research the principle of natural selection. For a time even the workers' movement in Germany hoped for a "natural" development towards socialism, and not surprisingly refered to publications from HAECKEL. ${ }^{7}$

At about the same time the German landscape architect Leberecht MIGGE (1881-1935) hoped for a "development of the working classes according to nature". ${ }^{8}$ Also in Germany the landscape architect Willy LANGE published in 1912 his book Garden Design of the New Times (Gartengestaltung der Neuzeit), in which he advocated a "biological aesthetics". ${ }^{9}$ LANGE who clearly was influenced by HAECKEL and DARWIN wanted the plants to be grown in a garden according to what he called ecological principles. "Biological aesthetics" he believed would be coined by a time "in which biological knowledge dominates the Weltanschauung and in which biological harmonies of nature are felt and valued aesthetically". ${ }^{10}$ For LANGE then humans became factors which disturbed nature.

Another of the consequences of Social Darwinism was the interest in genetic manipulation with approval and even active support of the politically "best" who believe to be the only ones to show the further path for humankind and civilization. This is how by social mediation nature becomes loaded emotionally. The fatal consequences of such thinking should be well known, in twentieth century Germany at least, as a look into the ideas developed during National Socialism can easily reveal. Together with my colleague Joachim WOLSCHKE-BULMAHN I have shown how such ideas with genocidal consequences for many of those who then were considered "Untermenschen", low ranking humans, related to landscape architecture and National Socialism. ${ }^{11}$
In many publications of the twentieth century a biological way of looking at the world became more and more popular. In late twentieth century it was the so-called biosphere which was looked at. Mankind with its spiritual, intellectual, and social dimensions was not part of this ecological reasoning. It seems not surprising then to see representations of the city which claim to be ecological, and which at the same time almost completely neglect the manifold human relations and achievements in a city. As in late nineteenth century, some ecologists of the late twentieth century view big cities as elements which are destructive to what they consider as nature. ${ }^{12}$ If at all acceptable, then big cities seem "tolerable" only to these scientists. They seem to have difficulties to see any constructive forces in big cities. This is especially surprising since there is a worldwide trend to urbanization. Contrary to such ecologists' views the people, who are the driving force behind this trend, obviously very much prefer cities to those areas they come from.

The neglect of the social, economic, and political aspects of human development is a cardinal mistake of the so-called ecological point of view. This ecological view tries to make believe, that the incredibly complex process of the civilization of several hundred millions of people on this earth is negligible. As if it had nothing to do with ecology. This I find remarkable. How important it is to include the social, political, and economic dimensions of human civilization must be obvious to all who think of changing a situation from bad to good. Once it is understood that the change can not become effected on an individual basis but can only become effected if forces are joined, if coalitions are formed, and if political activity is developed, the need for knowledge about such an "ecology" of humans is clear. This was clear to the founders of social ecology in the 1920 s already.

"The science", Robert E. PARK, one of the founders of such ecological thinking, wrote, "which seeks to isolate these factors and to describe the typical constellations of persons and institu- 
tions which the co-operation of these forces produce, is what we call human, as distinguished from plant and animal, ecology" 13 PARK's co-author, Roderick D. McKENZIE, "in the absence of any precedent ... tentatively define(d) human ecology as a study of the spatial and temporal relations of human beings as affected by the selective, distributive, and accommodative forces of the environment" ${ }^{14}$ According to McKENZIE "the human community differs from the plant community in the two dominant characteristics of mobility and purpose, that is, in the power to select a habitat and in the ability to control or modify the conditions of the habitat" 15

Each discipline must try to establish a theory if it wants to find a framework for the various individual research results. This is far from an easy task. It appears that in the landscape architecture of the late twentieth century the term "ecology" often is used as a kind of disguise for the fact that there hardly is any theoretical framework which would enable to locate whatever "ecological" results. My impression is that in a number of other disciplines, for example in medicine, in music, in chemistry, in physics, ${ }^{16}$ and in literature, there is more theoretical reasoning than in landscape architecture which often claims to be the only discipline with an ecological view as opposed to all the other disciplines.

With respect to landscape architecture in Germany this becomes even more strange given the still strong interest in what has been called 'land maintenance' (Landespflege) by National Socialist landscape architects. Even half a century after the liberation from National Socialism there are still difficulties to clearly depart from such positions. ${ }^{17}$

\section{Garden culture and open space development as part of a democratically constituted society}

The social scientist Norbert ELIAS, who thoroughly studied the process of civilization in European societies, developed a meaningful hypothesis. His research revealed that in the course of civilization the need to check emotions, passions, and impulsivity became more and more significant. ${ }^{18}$ In support of this hypothesis I think it will become more and more meaningful for the development of civilization to check democratically how the different groups of a society appropriate and dominate nature. Within such a procedural framework paths may open up towards a (garden) theory as part of the issues of garden culture and open space development in an urbanizing world of the twenty-first century.

If the idea of garden culture and open space development is seen as a path to suggest to people a conscious and long-range exchange with non-human nature, then each horticultural and open space-related activity could become questioned, as any other human activity, how deliberate and how far-reaching it has been conceived. In this case 1 take it for granted that those who comply with these standards by themselves may ask others what they think about such standards. Garden culture and open space development take off from a democratically constituted state, and understand that their interests compete and must become effected in a rational discourse with other legitimate open-space-related interests in a society.

Contrary to an "ecologically" oriented landscape architecture which is based on the application of selected scientific results only, garden culture and open space development explicitly and additionally apply results from social science and art history research for the implementation of their goals. Garden culture and open space development essentially embrace the socially mediated aspects of the history, the design, and the use of gardens, parks, and other open spaces. To view the design, the use, and the history of gardens, parks, and other open spaces from a seemingly objective "ecological" interest of "nature" clearly contradicts this understanding.

When humans claim to plan in the interest of nature they overlook that this is nothing else but one of many human interests. The nature which antecedes human history and civilization is the nature "which nowadays exists nowhere any lon- 
ger" as Karl MARX (1818-1883), the German social philosopher and chief theorist of socialism and communism, has realized in the nineteenth century already. ${ }^{19}$ So even non-human nature, also plants and animals, can only become understood as a product of societal exchange. This holds also true for landscape, an equally woolly and special category in landscape architecture, which every now and then is considered to be timeless.

Landscape architects and others, who believe they can make a contribution to improve the open space situation of other people, should try, wherever they may work, to understand the meaning of open space for various groups of the population. For that it may prove useful to make oneself aware of the meanings oneself has attached to various open spaces in the course of one's own life. As research shows it is wise to be modest with assumptions about the use, the appreciation of the design, and of the history of open spaces. Qualities and quantities of open space may become appreciated fairly different in various social situations. However, to be able to discover such variations, to address them both from a designer and a user perspective is a meaningful activity of garden culture. To some extent, and in some countries, one can even refer to empirically researched material.

\section{About the contradictory perception of nature}

Since about the mid 1970s in Germany many people who quite frequently associated in groups and called themselves 'Buergerinitiative' citizens' initiative, voiced their interest in higher quantitative and higher qualitative standards of open spaces not only in the cities but also in rural areas in Germany. Over the years a "green" movement formed which after a while also took part in the party-political process known as democracy. There, for the first time since the Weimar Republic, the meaning of open spaces was made a matter of public interest again. This formation took place in large cities and in urban agglomerations.
There the number of votes in democratic elections became large enough to first influence open space politics on local, later also on state and federal levels.

Not surprisingly some of the interests voiced went beyond what others felt they could bear. More often than not this related to rural areas with an agricultural background. Here the eco-urbanites were sometimes met with considerable resistance if not hostility. It seems characteristic for many eco-urbanites that they share a fairly ambivalent relation to non-human nature as it is still present in some rural areas in Europe.

They tend to overlook that even agriculture, which many consider a kind of pre-industrial activity, has become completely industrialized. So increasing numbers of people have to realize that the long-standing tendency towards urbanization and industrialization, which they themselves propel, has also encompassed agriculture. Here they seem to realize the discrepancy between the openspace nature which they have been shown at schools and in art museums as 'landscapes' of the eighteenth and nineteenth centuries in paintings and in literature and the industrialized agricultural areas next to the cities in which they live a relatively comfortable life.

Some voice that experience in public. This is one side of the relationship to non-human nature. From here one could approach an "ecological" idea to create a paradise although Christian belief tells that Christians at least have been driven from paradise a long time ago. Some may reflect their own distance from what they consider nature and realize that it will always remain a dream. The best they can do is dream it up, write about it, compose it, put it on stage, or paint it. Some may have realized that there is no way to paradise, and some may even reject the idea to ever be in a paradise. Most of us are not interested to really live in nature. From our history of civilization and urbanization we have learned that we are much better off if we perceive this non-human nature selectively, and only if it is made ready for our ways of perception and experience. 
So "close to nature" is a fairly inept category if one wants to locate garden culture and open space development within the framework of social and political activities. What everyone can do is to try to locate herself and himself in a way which allows to see and reflect the changes in the perception of "nature" which accompany her or his life with respect to the various attempts to get a sense of the kind of nature appropriation considered necessary for both spiritual and material enjoyment. When I try to imagine what the twentyfirst century may have in store for garden culture then I think it may not be a long way to go to design your own flowers and plants. What consequences this will have I do not know. However, I think it would be wise for those interested in garden culture and open space development to start thinking about such issues. As I have just indicated there never was and there will never be an unchanging position. Thus trying to make sense I understand garden culture and open space development as part of an approach to democracy.

\section{Some examples for garden culture and open space development activities in the last quarter of the twentieth century}

Although I have been explicit about the relative social and political meaning of garden culture and open space development there is a host of related tasks for the urbanizing societies of the twenty-first century. Garden culture and open space development can participate in the ongoing process of civilization and urbanization. However, it is necessary to soberly assess the role this field can play.

First of all it is more important to talk to people and to offer assistance than to commission another ecological analysis or another biodiversity study. Second, it is more important to apply scientifically proven results and artistic creativity than to conjure mystic ideas about gardens and landscapes. As the 'Kleingarten' movement in Germany can prove since more than one hundred years, gardening in an association is a pow- erful political and social facet of urban garden culture. ${ }^{20}$

Since about a quarter of a century the American community garden movement which feels inspired by the 'Kleingarten' movement can point to almost incredible successes in building a sense of urban community in areas which were believed to be lost socially and politically. ${ }^{21}$ An international conference in Berlin, Germany, from 21 to 25 July 2000 addressed the return of the gardens and subsistence agriculture as issues in many countries around the world. ${ }^{22}$ To enjoy garden culture and other open space related recreation in an urban environment needs the articulation of such interests in the various political bodies of the communities, the counties, the states, and the nation. Such interests also need to become integrated into party-political programs in order to become effective in a democratically constituted society. ${ }^{23}$

Ideas about garden culture and open space development should not become presented entirely independent from other issues or even as a kind of martyr program, at least not in the public sector. For example those who are actively providing open space for garden culture, for children's' playgrounds, for open space sports activities, etc., can and should join talks about crime prevention in urban environments. If they do not, such values of open spaces will not be known to politicians and other decision-makers. Instead of "ecological" ethics social practice is asked for in garden culture and open space planning. Next to talking, to provide both written and designed plans on various levels of political decision-making is an important tool.

The planning levels on which activities in favor of garden culture and open space development can be taken I have compiled in a table which I have called "Scheme of Open Space Plans" I do not have the space to explain all of this in detail but want to point to the three levels of planning. These levels themselves are not separated so sharply from each other as the scheme might suggest. One is the level of the open space system in 
a region or a city. Another is the open space structure in a city or a smaller political unit. And another one is the open space infrastructure, that is the elements which shape a given open space. In one way these plans relate to the invention of land use planning in the late nineteenth century in Germany. In another way they are a far cry from the late nineteenth century since such plans have become more and more refined.

Another point seems important for the future of urban garden culture and open space development. Although exchanges about the amounts of leisure were quite popular in the 1960s and 1970 s in Germany and elsewhere in Europe, it is far from clear as to how future amounts of leisure will be distributed. The assumption that leisure will increase seems questionable in many instances. As a concomitant to this, the use of open space needs to be reflected also. Will it increase or will it decrease or will it be a more or less stable variable?

At least with respect to the interest to have a place near the water, and enjoy some music, not much seems to have changed within the twentieth century in Germany. Also it appears as if during the second half of the twentieth century open space related interests have increased rather than decreased. However, one can also assume that a number of once self evident open space activities tend to become located in buildings. This process is known as the housification of open space activities. This relates for example to activities such as soccer, climbing, swimming, tennis, and also to the crystal palaces in which we tend to house some of the plants and animals which can not stand the local climate, ${ }^{24}$ etc.

When the nuclear power plant in Chernobyl blew up in spring 1986 not only the idea to use open space for the sake of enjoyment and health but also the idea to grow food outdoors was severely shaken in many European countries, including Germany. When in spring 2000 the major nuclear powers of the world agreed to stop the production of nuclear weapons this may be taken as a first step to a needed ban of this mad tech- nology. It will still be a long way before the final agreement will be reached. Nevertheless I think it was mainly due to the interest of many people to enjoy recreation in and fruit and vegetables from uncontaminated outdoors, voiced through the environmental movement, which enforced this agreement.

Frankly, I find it strange to read in contemporary open space plans more and more information about the frequency of butterflies and certain plant species in a given location than about the quality and quantity of various open spaces which people can enjoy in a city. Other categories such as for example open spaces in residential areas seem to be completely neglected. At the same time the unequal distribution of open space is easily visible in the cities. This is not a law of nature. It is man-made. To address such unequal distribution of open space is a meaningful task of open space planning. ${ }^{25}$ Shall the situation become worse, shall it become stabilized, or shall it become improved? What then does that mean for the use and the design of the open spaces? To me, answers to these questions seem more relevant than the ubiquitous hints towards endangered plant and animal species.

If, what I have called the ambivalent relationship of humans to non-human nature, is valid then it should be clear that the vast majority of us have no interest to return to a pre-industrial, nineteenth-or-even-eighteenth-century-agricultural way of existence. Then garden culture and open space planning should have a closer look at such mediated nature appropriation and its impact. Also the goals which garden culture and open space planning feel obliged to and how they relate to other goals in a society should become a matter of public debate. Should the amount of open space in a city become reduced to the lowest quality and smallest quantity? Should all of a city become a nature protection area? Should all available open spaces become developed for industrial and commercial activities? Who should decide about such issues?

Plans, designs for, and histories of parks 
and gardens and other open spaces should attempt to bring into public debate those values, which encourage staying outdoors. This is a vast field, which has only marginally been ploughed. As long as millions are spent for the mapping of plant and animal species only, and not for urgently needed research into the ever changing needs and interests of people the basis of landscape plans lack the most important part.

Strange as it may appear, quite frequently the open space related interests fight each other. One example is the fight for more funds and publicity against other interests. Charles R. JORDAN, the dynamic director of Parks and Recreation in Portland, Oregon, is not afraid to talk about a "war" which the American National Parks wage a-gainst the parks in the cities and the big agglomerations. JORDAN found that in the United States of America ninety percent of the state money became invested into the national parks, which only ten percent of the population visits. Whereas only ten percent of these funds are supplied for state parks and urban parks which are frequented by ninety percent of the population. ${ }^{26}$

Another example is the fight between those who believe the use of so-called "native" plant species must become enforced against the use of so-called "non-native" plants. This fight is not new. It has shown up several times during the twentieth century in Germany. Especially since the 1980s the stupidity of the case seems as attractive as ever. ${ }^{27}$ On a larger scale such absurdity even made its way into international literature. Siegfried LENZ, a well-known German writer, addressed this in his novel "The Training Ground" in 1991,28 and concluded: "Never trust anyone who preaches genuineness and purity" he wrote. "The apostles of purity bring us nothing but de-saster" In many instances, I think, it would be much wiser to join forces rather than to fight in such sideshows. The more recent invention of genetically engineered plants and the increasingly industrialized production of plants may provoke similar reactions.

Planning and designing open spaces is nothing else but a kind of interest representation and thus needs to be part of a political process in a democracy. On the other hand planners and designers should not believe they are politicians simply because they have understood that they are part of political processes.

Especially as a conscious participant in the political processes one should be clear about their complexity which sometimes may make it difficult not to loose track of the goal. However, this should not detract from asking questions and se-eking for answers, which allow to reach the stated goals of garden culture and open space development. That is basically different from waiting for the questions from politicians, then answer them, and then name the instruments by which to reach best the goals of the politicians.

Wherever activities of garden culture and open space development take place they have to take into account the social situation and the economic and spatial conditions if they want to succeed. Such goals and claims have to be presented and discussed in the context of the governing ideas about a social state, equal opportunities for all, social justice, constitutionally guaranteed social rights for all, free selection of profession, right for education, free education, free commercial activity and so on. Social, economic, political, and spatial conditions change and are changeable. Those interested in garden culture and open space development should make suggestions and engage themselves.

\section{Notes}

1 Haeckel, Ernst 1866: Generelle Morphologie der Organismen, Berlin.

2 In early nineteenth century Karl Ernst von BAER (1792-1876), a professor of biology at the univer- sities of Wuerzburg, and later of Koenigsberg and St. Petersburg (from 1834 onwards), had shown that the development of the embryo in different animals is similar in its early stages. This he made 
a basis for a general evolutionary theory (see Baer, Karl Ernst von 1828-37: History of the Development of Animals, two volumes, St. Petersburg).

3 When one has a closer look at embryos, then one can show that in early stages the embryos of fish, birds, and mammals are fairly similar. So for example one can observe the nascent stages of gillclefts (Kiemenspalten) with humans and with fish. Wheras, however, gillclefts gradually develop into such with fish and function as such they gradually disappear with the development of the human embryo save a somewhat changed gillcleft which ultimately becomes the Eustachian tube. The Eustachian tube is a hollow structure of bone and cartilage which extends from the middle ear to the rear of the throat and serves as equalizer of air pressure on either side of the ear drum. As experience with flying can show, when you feel an earache when the air pressure falls to quickly in landing, this is usually related to the Eustachian tube.

4 In 1905, some forty years after HAECKEL had published his "Generelle Morphologie der Organismen". the American plant ecologist and pioneer in the study of succession, Frederick Edward CLEMENTS (1874-1945) published his book "Research Methods in Ecology" It was widely received in the AngloSaxon world and spread the notion of ecology.

5 The opposites of monism are dualism and pluralism.

6 Darwin had pointed out the existence of variations, i.e. differences among members of the same species, and suggested that the variations that prove helpful to a plant or an animal in its struggle for existence better enable it to survive and reproduce. These favorable variations are thus transmitted to the offspring of the survivors and spread to the entire species over successive generations.

7 See Groening, Gert and Joachim Wolschke-Bulmahn 1986: Soziale Praxis statt oekologischer Ethik, Zum Gesellschafts- und Naturverstaendnis in der Jugendbewegung unter besonderer Beruecksichtigung der Arbeiterjugendbewegung, Archiv der deutschen Jugendbewegung, Jahrbuch 15/ 1984-85, 20 1-252, Burg Ludwigstein; see also e.g. Bruno, Adolf 1913: Von der Schönheit in der Natur, Arbeiter-Jugend, 5, 44-45.

8 Migge, Leberecht 1910: Mehr Oekonomie, Gartenstadt, Mitteilungen der deutschen Gartenstadtgesellschaft, 4, 10, 109-113, here p. 112.

9 Lange, Willy 1912: Gartengestaltung der Neuzeit, Leipzig.

10 Lange 1912 , here p. 50.

11 See Groening, Gert (ed.) 1996: Planung in Polen im Nationalsozialismus, Berlin; see also Groening,
Gert 1996: Naturschutz und Nationalsozialismus, Gruener Weg 31 a, Zeitschrift des Studienarchivs Arbeiterkultur und Oekologie, 10, Dezember, 425; see also Groening, Gert and Joachim Wolschke-Bulmahn 1993: 'Ganz Deutschland ein grosser Garten', Landespflege und Stadtplanung im Nationalsozialismus, Kursbuch, 112 , 29-64; see also Greoning, Gert and Joachim WolschkeBulmahn 1987: Politics, Planning and the Protection of Nature, About Political Abuse of Early Ecological Ideas in Germany between 1933 and 1945. Planning Perspectives, 2, 2, 127-148; see also Groening, Gert and Joachim Wolschke-Bulmahn 1987: Die Liebe zur Landschaft, Der Drang nach Osten, Zur Entwicklung der Landespflege im Nationalsozialismus und während des Zweiten Weltkrieges in den 'eingeliederten Ostgebieten'. Arbeiten zur sozialwissenschaftlich orientierten Freiraumplanung, volume 7, Muenster; see also see also Wolschke-Bulmahn, Joachim and Gert Groening (forthcoming 2001): The National Socialist Landscape Ideal: Bodenständigkeit (Rootedness in the Soil), Etlin, Richard (ed.), Culture and the Nazis, Cambridge, Massachusetts.

12 See for example how Sukopp described in 1973 the ecosystem of a city.

13 Park 1925/1967. p. 1-2.

14 McKenzie, Roderic D. 1925: The Ecological Approach to the Study of the Human Community, Robert E., Burgess, Ernest W., and Roderick D. McKenzie, The City, 63-79, Janowitz, Morris (ed.), The Heritage of Sociology, reprint 1967 with an introduction by Morris Janowitz, Chicago, here p.63-64.

15 McKenzie 1925/1967. p. 64-65.

16 See e.g. Mutschler, Hans-Dieter 1993: Zwei Kulturen sind besser als keine, Wider die physikalistischen Ganzheitslehren, Merkur, 47, 1 1,998-1003.

17 See Groening, Gert 1999: Gartenkultur in Kleinund Hausgärten im historischen Wandel, Bundesverband der Diplomingenieure Gartenbau und Landespflege e.V. (Hg.), Beziehung, Mensch und Pflanze im Wandel der Gesellschaft - Garten, Park, Landschaft, BDGL-Schriftenreihe, 7-24, Bonn; see also Groening, Gert 1998: Die Suche nach der 'Landschaftsmitte' Kursbuch, 131, 55-69, Berlin; see also Groening, Gert 1997 : Ideological Aspects of Nature Garden Concepts in Late Twentieth Century Germany, Wolschke-Bulmahn, Joachim (ed.), Nature and Ideology, Natural Garden Design in the Twentieth Century, Dumbarton Oaks Colloquium on the History of Landscape Architecture, XVIII, 220-248. Washington, D.C.; see also Groening, Gert 1996: Der Ueberfall auf Polen und seine Auswirkungen auf das Konzept der deutschen Landespflege, Groening, Gert (ed.), Planung in Po- 
len im Nationalsozialismus, 91-105, Berlin.

18 See Elias, Norbert 1976: Ueber den Prozess der Zivilisation, two volumes, Frankfurt am Main.

19 Marx, Karl und Friedrich Engels 1959: Werke, Band 3, Berlin; see also Groh, Ruth and Dieter Groh 1993: Natur als Massstab - eine Kopfgeburt, Merkur, 47, 11, 965-979.

20 See Groening, Gert 1974: Tendenzen im Kleingartenwesen dargestellt am Beispiel einer Grossstadt, Beiheft 10, Landschaft + Stadt, Stuttgart; see also Groening, Gert, and Joachim WolschkeBulmahn 1995: Von Ackermann bis Ziegelhuette, Ein Jahrhundert Kleingartenkultur in Frankfurt am Main, Studien zur Frankfurter Geschichte, volume 36, Frankfurt am Main; see also Groening, Gert 1996: Aspects of Community Gardening in Germany, City Farmer, Canada's Office of Urban Agriculture, City Farmer's Urban Agriculture Notes, Internet Publication, Vancouver, British Columbia; see also Bertram, Christian, and Gert Groening 1996: Leipziger Schrebervereine und ihre gesellschaftspolitische Orientierung zwischen 1864 und 1919, Frankfurt am Main; see also Groening, Gert 2000: Aspects of Community Gardening Politics in Berlin, Germany, between 1985 and 1995, Proceedings of the XXV International Horticultural Congress, Part 13, Acta Horticulturae, volume 532, 167-179.

21 See Groening, Gert 1997: Zur Entwicklung der urbanen Gartenkultur in Nordamerika, Stadt und Gruen, 46, 8, 563-572; see also Groening, Gert 1998: Zum Stand der urbanen Gartenkultur in den USA, Gaertnern als gemeinschaftsfoerdernde Taetigkeit?, Stadt und Gruen, 47, 11, 771-777; see also Groening, Gert 1999: Kann man "ImmerGruener" werden?, American Community Gardening Association Jahreskonferenz 1998 in Seattle, Washington, Gruener Weg 31 a, Zeitschrift fuer die Sozial- und Ideengeschichte der Umweltbewegungen, 13, September, 6-18; see Payne, Karen, and Deborah Fryman 2001: Cultivating Community, Principles and Practices for Community Gardening As a Community-Building Tool, American Community Gardening Association, Philadelphia.

22 See Meyer-Renschhausen, Elisabeth, and Anne Holl (eds.) 2000: Die Wiederkehr der Gaerten, Kleins- tlandwirtschaft im Zeitalter der Globalisierung, Muenchen.

23 See Milchert, Juergen 1984: Tendenzen der staedtischen Freiraumentwicklung in Politik und Verwaltung, Arbeiten zur sozialwissenschaftlich orientierten Freiraumplanung, volume 5, Muenchen.

24 See for example COLE, Dominic 2000: Parks in the Place of Former Industrial Sites, The Eden Project, Die Gartenkunst, 12, 2, 222-226.

25 See Groening, Gert 2000: Zur Geschichte schichtspezifischer Freiraumversorgung, Harth, Annette, Scheller, Gitta, and Wulf Tessin (eds.), Stadt und soziale Ungleichheit, 102-119, Opladen.

26 See Groening, Gert 1999: Aspekte der Freiraumplanung im amerikanischen Nordwesten, Stadt und Gruen, 48, 10, 674-679, here p. 677

27 See Groening, Gert and Joachim Wolschke-Bulmahn 1992: Some Notes on the Mania for Native Plants in Germany, Landscape Journal, 11, 2, 116 126; see also Groening, Gert and Joachim Wolschke-Bulmahn 1987: Die Liebe zur Landschaft, Teil III, Der Drang nach Osten, Zur Entwicklung der Landespflege im Nationalsozialismus und während des Zweiten Weltkrieges in den "eingegliederten Ostgebieten" Arbeiten zur sozialwissenschaftlich orientierten Freiraumplanung, volume 9, Muenchen, especially chapter "5.3 Fremdlaendische Pflanzen in der ausserstaedtischen Landschaft und Bodenstaendigkeit als Planungsideal" The following may serve as a recent example for this. In 1993 a number of trees were to be cut down in Berlin for the enlargement of a hospital. The respective authority found that no trees at all must become felled. However, after close inspection it was found that there grew an American oak and a German oak. Once this was detected the German authority gave permission to fell the American oak. The American oak was not German and thus considered less valuable. In the United States of America the state of Indiana in the year 2001 wants to get rid of its long-standing state flower, the peony, because it is not considered native.

28 Lenz, Siegfried 1991: The Training Ground, New York, published in German as "Der Exerzierplatz" in Hamburg in 1985. 